\title{
КАТЕГОРІЯ SАСRUМ В ХУДОЖНЬОМУ УНІВЕРСУМІ ВАЛЕРІЯ ШЕВЧУКА
}

Донченко Л. О. Категорія sacrum в художньому універсумі Валерія Шевчука.

Статтю присвячено функціонуванню категорії sacrum в художньому універсумі Валерія Шевчука. Зосереджується увага на різних його іпостасях: Бог $є$ Творець усього сущого, Бог $є$ Слово, Бог $є$ Любов, Бог $є$ Володар Раю. Образ структурує цілісний інтертекст.

Ключові слова: sacrum, автор, текст, модус, час, простір. 
Донченко Л. А. Категория sacrum в художественном универсуме Валерия Шевчука.

Статья посвящена функционированию категории sacrum в художественном универсуме Валерия Шевчука. Уделено внимание разным его ипостасям: Бог есть Творец всего сущего, Бог есть Слово, Бог есть Любовь, Бог есть Властитель Рая. Образ структурирует целостный интертекст.

Ключевые слова: sacrum, автор, текст, модус, время, пространство. Schevchuk.

Donchenko L. O. The category of sacrum in the artistic universe created by Valeriy

The article examines functioning of the image of God in the artistic world created by Valeriy Schevchuk. It pays special attention to a variety of God's hypostases: the Creator of Entity, the Creator of God's logos, God as Love, the Lord of Paradise. A sacred image structures the wholeness of the intertext.

Key words: sacrum, author, text, modus, time, space.

Категорія sacrum $є$ багаторівневою структурою, оскільки функціонує на онтологічному, аксіологічному та феноменальному рівнях. Перш за все sacrum $є$ категорією онтологічною, оскільки саме через неї свідомість здійснює акти трансценденції. Філософія та релігієзнавство утвердили два підходи до онтологічного аспекту сакрального: увесь світ $є$ сакральним, бо створений Богом. Інший погляд - світ профанний і трансцендентно не є його складовим. «Священне завжди перебуває на межі між іманентним i трансцендентним як лінія горизонту іманентного буття, що вказує за онтологічний обрій останнього - на трансцендентне...» [4, с. 39]. Категорія sacrum має аксіологічний вимір, адже передбачає естетичний модус. 3 феноменологічного погляду - це «своєрідний епіфеномен, дивний і вражаючий» [6, с. 23].

У філологічних науках означився напрям, який свідчить про глибокий інтерес до рівнів вираження сакрального в художніх творах. Зокрема, про це свідчить фундаментальний збірник «Sacrum і Біблія в українській літературі» (за редакцією I. Набитовича), у якому опубліковані матеріали вчених літературознавців 3 університетів України, Німеччини та Канади, що репрезентують різні стратегії методологічних підходів до висвітлення сакрального в релігійних та художніх текстах. Україна представлена знаними в цій царині іменами: Ю. Пелешенко, Я. Поліщук, Ірина Бетко, Зоряна Лановик, М. Бондар, В. Антофійчук, А. Нямцу. Власне, у цій науковій парадигмі ми представимо функціонування категорії sacrum у художньому універсумі Валерія Шевчука.

(с) Л. О. Донченко, 2012. 
До осягнення невимовної сутності Всевишнього людство прагне віками. Трансцендентний феномен на шляху сходження до істини залишається на дальніх горизонтах людської свідомості (термін належить Е. Гуссерлю [5]). Проте філософи, психологи, художники, письменники фіксують моменти інтуїтивного осяяння - наближення до вищої субстанції - і своє внутрішнє бачення переливають у неповторні образи. Недосяжний у своїй великості і близький у своїй милості він наближений до нас Ликом, явленим найвідважнішими дітьми його.

Валерій Шевчук надзвичайно делікатно i тонко осмислює співвідношення людської душі з Вічним Духом: «... людина існує не лише для себе $i$ для світу, котрий довкола, тут $i$ тепер, а й для минулого і прийдешнього, котрі утворюють певну єдність, цілісність. Власне, це і є та вічність, яку можемо означити словом Бог. Жодні духовні пошуки без поєднання з Вічним Духом неможливі. Ось чому у своїй життєвій мандрівці людина підноситься до Вічності, тобто до Бога. Боюсь, однак, щзо надто часто згадуючи це ім'я чинимо певне блюзнірство - а цче вже початок смерті. Бог для людини закритий, він є вічною Таємницею... Можлива лише суто особиста потаємна розмова з ним...» [8, с. 56].

У своїй творчості Валерій Шевчук осмислює тему «Бог і людина». Ми намагатимемось прослідкувати розгортання смислообразу, ідучи за логікою авторської уяви. У повісті «Ілля Турчиновський» образ Всевишнього змальовано згідно 3 народними уявленнями: Бога Отця він (народ) уявляє під впливом іконографії не інакше як в образі святої людини (та саме усе ж Бога), старого, 3 великою сивою бородою, що живе в першому раю, створеного ним особисто для себе... [3, с. 70]. Літературний персонаж переживає найжорстокіші переживання. Автор передає стан психологічного напруження - розпалена уява понівеченої людини малює фантастичні, моторошні картини: степом мчать коні з людськими головами, в яких засіли леви, передвісники білої машкари в чорній одежі. Свідомість згасає і являє образ Божий: «Червоний обідещь засмоктав мене до решти, почав обертатися швидше і швидше, аж доки не загусла моя свідомість і не побачив я на небі хвоста, щу курівся і сипав зорями. Мене підняли, земля захиталася далеко внизу, дивно закруглена і незвичайна.

- Алюди де? - спитав я.

- Оті комахи хіба не люди? - відповів мені білий як сметана дід, щуо сидів на хмарі, спустивши з неї босі ноги $i$ завзято кушпелячи 
здоровенну глиняну люльку» [13, с. 122]. Виписаний у притаманній українському гумору добродушній манері, «поселений у видимому небі», Спаситель подає надію на життя. Субстанційний атрибут його сутності - його Великість перед малістю людською не жахає, а дивує і захоплює. Власне, та ж межова ситуація повторюється у повісті «Мор». Поранений юнак у стані забуття немов провалюється крізь землю, a, повернувшись до життя, звертається до Бога. Це найоб'ємніша авторська характеристика, бо Всевишній постає в багатьох іпостасях: «Коли очуняв - побачив небо - високе, святкове 3 ошатними хмарами. Сонще щедро розсипало проміння й ранило очі. Тоді він заплющився і проказав молитву до того, хто в багряницю одягнений, хто славний милосердям $i$ як драною одежею покритий покірливістю. До того, хто увінчаний вінком звершених чеснот, хто переселився з землі в небеса і хто дивиться на нас; до того, зрештою, хто шле нам долю нашу і наше покликання; странньому конче треба, щуоб звістив він йому, куди має повести його і навіщо. Так дивно почав його спитувати: повідж і звісти мені», - попросив він із упокоренням, відчуваючи солоний смак власних сліз...» [16, с. 368]. Як бачимо, у зображенні зовнішніх ознак Господа автор дотримується іконографічних приписів - «у багряницю одягнений». В етичному сенсі людських сподівань на спасіння превалює прославлене милосердя Боже. Стражденний шукає спорідненість i 3 вищим началом i знаходить його в покірливості: він немов «задобрює Всевидящого», звертаючись «до того, хто увінчаний вінком звершених чеснот», у сподіваннях кращої долі і всією душею прагне розгадати тайну спитування. У ньому живе надія на діалог і упокорюючись, странній благає: «повідж і звісти мені». Цю пристрасть можна порівняти лише із благоговійним прислуханням до Слова батька на смертному одрі. «... Заповідь може дати тільки особистий Бог. Який не тільки має силу сказати про Себе із-за межі часу і простору: «Я», - але ще й назвати себе співрозмовнику: «Бог твій». У цьому вся суть Ветхого Завіту: в невичерпній здатності дивуватись, що Бог усього сущого, який створив небо і землю, Деміург, видимий на віддалених горизонтах міфології і доктрин, виявився таким близьким: що він - мій Бог. Як сказано в зачині псалма 62: «Боже, ти Бог мій», - писав відомий культуролог С. Аверінцев [1, с. 14].

Психоаналітики шукали шляхів до Діалогу i знайшли в позасвідомому: Бог творить через сон і символ, - вважав К. - Г. Юнг (ㄱ Л. О. Донченко, 2012. 
[26, с. 93]. В І. Я. Франка знаходимо: «Сонна фантазія не любить абстрактів і загальників і залюбки трансформує їх на мову конкретних образів» [10, с. 113]. Вал. Шевчук художньо мислить згідно з цією філософською парадигмою. У повісті «Птахи 3 невидимого острова» мрія-бажання відчути доторк Божий реалізується у сні-маренні, що спадає на білого як лунь попика, якого закружляло вертепне дійствосвідчення на чолі з Королем і Смертю. Його опановує страх, і він по-своєму інтерпретує Свангеліє: «Бог скаже раз, - прочитав він, коли на те не вважають, ще й другий раз. У сні, у нічному видиві, коли сон находить на людей, коли дрімаємо на ложі, тоді він відтуляє в чоловіка вухо $і$ втискає свою науку...» [22, с. 376]. Таке довірливе на рівні сенсорних імпульсів осягання Божественного Логосу немов відгортає завісу сакрального таїнства і прилучає людину до вічності. Вал. Шевчук не залишає свої героїв у трагічні хвилини без хай тремтливого, іноді непевного, палахкотіння в їхніх душах Свічі Віри. «Олізар лежав напівмертвий на порожньому ложі, розкидавши руки $i$ ноги, наче розп'ятий, наче птах у невиданому польоті...» [21, с. 249]. «... I тоді змилостивилася над ним вишня сила...». В уяві полонений лине до «отчого дому», залитого сонячним промінням. «I хоч який немічний був його батько, скочив він з відчаєм, простяг благально руки догори, до тих вітрів, яких скільки молив про милість собі, до Бога, який став Богом, через те, щзо страждав...» [21, с. 252]. У містерії Буття мука земного батька, занурена в самість, проектується на духовну жертовність Отця небесного, який бачить смертельну тугу в очах розіп'ятого сина. Та крізь есхатологічний план прояснюється торжество величного свята життя - Воскресіння. Екстатичний порив до буття в цьому світі благословенний Творцем, бо «... сам він напрочуд різновимірний, ніколи не буває застиглий $i$ млявий, він весь у русі, у безначальному прочесі творення, народженні і вмирання, він - як дерево несмертельне: одні гілки на ньому всихають, а інші наростають. Листя з'являються і падає, а він завжди є, поки взагалі існує у всесвіті життя. Життя, друже мій, - ие $i$ є Він, иее те, щуо рухає світ $i$ дає йому несмертельність. Немає образу, щзоб відтворити його, - він сіє на нас страх, радість і щастя, бо він дух животворний» [17, с. 181].

Основна заповідь Божа - заповідь любові. Найважче за все здійснити в цьому житті релігію любові, але від цього сама релігія не менш висока та істинна - вважав Ніколай Бердяєв [2, с. 64]. Ідейним підтекстом усіх творів Вал. Шевчука $є$ пошуки гармонії і любові. 
У повісті «Мор» цей постулат найбільш чітко маніфестує моровий странній, розумовими зусиллями якого врятовано місто. Апокаліптична картина мору змодельована завдяки емоційно наснаженим деталям: запах смерті, валки, на яких везуть померлих, нестерпна спека, рій мух... Розрішенням напруги - благодатний дощ. Странній долає символічний шлях до неба, і вистраждане почуття щастя породжує думки: «Ми повинні любити одне одного, ми життя творимо, а коли ненавидимо - нищимо його. Хай же буде звершена у нас любов, а не ненависть. Тільки по цььому пізнаємо, щзо ми справжні суть і щзо потрібні у изьому світі. Наш Бог - любов, $і$ хто пробуває в любові в Бозі пробуває. Тільки любов'ю міряємо наші вчинки $i$ дї немає у світі вищого суду» [16, с. 457]. Всім, хто жив згідно з його заповіддями, Всевишній посилає надію на райське життя. Вал. Шевчук подає декілька варіантів опису раю, в яких віддзеркалені народні уявлення. Персонаж із повісті «Око прірви», ієромонах Автоном одної ночі мав видіння: побачив дивної краси долину, порослу лісами 3 плодових дерев, полями з усіляким їстівним зелом, 3 квітами, яких було аж надто багато, що покривали вільний простір $[18$, c. 58]. Розмаїття відчуттів охоплює Петра Легенького, коли його зір «прочинився, він побачив дивний ліс: росли в ньому небачені дерева і співали небачені пташки». Зорові й слухові образи підсилюються «чудовим запахом», від якого ясніло в голові і над усім цим «грала ладна музика» [20, с. 198].

Окрасою художньої тканини роману «Три листки за вікном» $є$ фрагмент - опис раю, що його можна вважати окремою новелою, настільки він художньо довершений і ейдетично багатогранний. Тому доцільно навести його повністю. Йдеться про вигнання Петра Легенького, який у безмірі відчаю кличе свою загублену кохану у незвідані краї... «Заведу тебе, Горпино, в чужий край, - казав мрійливо, - там у золотих коритах свині мигдаль їдять, а горобиі ходять у срібних панчохах. Там лобода росте, як у нас дерева, $i$ родять на ній вареники та пироги. Я вже напитав туди дорогу $і$ ось веду туди тебе.

Горпина сміялася і хитала недовірливо головою. - Чи не той цее край, - спитала вона, - де гарбузи мають золоте насіння, отаке як биті таляри?

- Еге, той, - підхоплював Петро. І гарбузи ичі не валяються на городах, як наші, а висять у повітрі, як надуті пузирі. Вони так $i$ (ㄱ Л. О. Донченко, 2012. 
рвуться в небо і гудиння їхнє таке натягнуте, щзо торкни ненароком $i$ зазвучить наче струна...

Стояло в повітрі натягнуте гарбузове гудиння, десь високо біля хмар золотом грали роздуті гарбузи, яскраво-білі свині ішли по кисельному березі щзб напитися з річки молока; горобець у срібних панчішках сів на край золотого корита $і$ зацвірінчав; хтось невидимий може вітер, а може якийсь чарівник торкав огудиння-струни: тиха музика наповнювала повітря, начебто гули десь поруч важко крилі джмелі: мед крапав із вербового листя $і$ під кожною вербою лежало по медовій колод $i$; лобода тягла м'яке зелене листя $i$ з нього звисали рум'яні випечені пироги» [20, с. 189-190]. Опис чудесного краю викликає спектр асоціацій: тут зафіксовано і константи народного бачення (річка «в кисільних берегах», «рум’яні пироги» між зелені); і тонко завуальовано авторську іронію («свині їдять із золотих корит», «цитата» із статей «мрійників» про комуністичний рай): і наші читацькі почуття зворушені образом «горобців у срібних панчішках» (срібні панчішки - ремінісценція із легенд про благородних лицарів, а сіра пташка символізує вірність рідній землі - згадаймо алегоричну поезію Лесі Українки «Мамо, йде вже зима...») [9, с. 82-83]. До речі, у художньому світі Вал. Шевчука птахи виконують роль зв'язківців між небесним і земним. Вони можуть символізувати Мрію-втіху («Птахи 3 невидимого острова»), Спокусу («Дім на горі»), Смерть («Постріл»).

Кардинальна онтологічна проблема - як утворено універсум? постійно тривожить уяву філософічно налаштованих героїв Вал. Шевчука. Мислителя Іллю Турчиновського в юні роки просвітлює Мудрий Старий: «Вогняне кільщее - це наше життя! Придивися... - иілий світ у колах. Сонце колом ходить, голубе коло крайнебо - з иьього кільия нам не вистрибнути, зелене - земля, яка тримає нас біля себе прив'язаних. Людське коло - ие пристрасті наші, від яких неможливо втекти...» [13, с. 32]. Символ кола відтвориться і у віршах його онука, випускника Києво-Могилянської академії Петра Турчиновського:

Світ навколо точить коло, крутить, колобродить.

Вітер стиха тужно диха, мов людина ходить... [20, с. 186].

Образ кола зустрічається в текстах у найрізноманітніших модифікаціях. М. Павлишин вважає його емблемою всього мітогенного задуму письменника. Критик простежує розгортання цього смислообразу. «Вже в одному з ранніх оповідань Вал. Шевчука сфера 
допомагає у втіленні імпресіоністичної тези, що світ - це те, що ми бачимо... Пізніше образ з'являється в непроглядній різноманітності форм: як страшне перекотиполе в апокаліптичних ландшафтах або гротесковий гарбуз, який котиться по полю; як часом лагідне, а часом загрозливе сонце; як страхітлива сферична хмара червоного пилу; як світлові кулі...; як циклічний шлях мандрівника..., який заблукав i намагається рухатися по прямій; як «великі сферичні тіла», що плавають по небу і в яких проглядають людські подобенства: витягнуті й зміщені наче в кривих дзеркалах» [7, с. 147]. Дослідник вбачає в повторному звертанні до образу кола прагнення письменника відновити у світі елемент сакрального, адже це посилання на християнський німб, або індуську мандалу. Зауважимо, що образ кола як принцип світоутворення найчастіше зустрічається у текстах, де події відбуваються за барокових часів. Бо вже люди раціонального XIX століття наділені скепсисом та іронією вважають, що «світ - дивоглядна сітка, в якій борсається тисячі і мільйони нещасних істот» [24, с. 373]. У розмові інтелектуалів Руданського і Метлинського світ думок та бажань порівнюється із «величезною безначальною сіткою, яку кинуто людям на голови» $[19$, c. 225]. У кінці трагічного XX століття романтична натура - Віталій Волошинський має сміливість стверджувати доцільність такого світопорядку: «... бо сітка на те й сітка, щоб існував той лад, який єднає атоми і всі навіть найдрібніші частки нашого буття» [23, с. 506].

Універсальні поняття, які утворюють центральну вісь координат моделі світу, - Час і Простір. У картині світу, витвореній уявою Вал. Шевчука, М. Павлишин спостерігає три топоси часу: циклічний час, прототипи якого вбачаємо у світогляді архаїчних, сільських, передцивілізаційних культур; лінійний час нескінченної хронології прогресії - час у формі, у якій він звичайно сприймається модерним секуляризованим людством; i хіліястичний час, який розглядає час лінійний як передмову до постісторії - есхатологічного, утопічного чи дистонічного стану, у якому вже не відбувається жодних змін [7, с. 150]. Поділяючи цю думку в розрізі нашої теми, ми виокремимо формальний емблематичний образ, який уособлює час. Це - Дзигар одвічний. У повісті «Крик півня на світанку» відбувається подія: беззастережна реальність биття годинника, що відлічує час хазяїна, коли той уже відійшов у небуття, набуває містичного звучання поєднаності живого і неживого. Годинник символізує ще й пам'ять роду, адже він перейшов у спадок від батьків і був придбаний у день 
народження померлого [15, с. 253]. Неясне відчуття спокою і ледь вловимої тривоги навідує стареньку із оповідання «Відлунок». Золотаві порошинки нагадують стрілки невблаганного годинника: «Здавалось, хтось сильний переставив його з гори і вона з жалем побачила, як безшумно спадає золотавий пісок ранку» [11, с. 410]. Ця метафора буде розгорнена і уточнена в повісті «Ілля Турчиновський»: розкодовується об'єкти змін - Сонце: «сонячне проміння несміливо проникало в сад і пестило прозорими пальиями горішні листя, крапало $i$ крапало - дзитар ранку...» [13, с. 89]. Схильний до філософських рефлексій, герой розмірковує над сенсом людського життя: «Знак неба, - подумалося мені, - ие знак нашої тлінності, а водночас - иее наші пошуки призначення у цььому світі. Це нагад, щзо людська метушня - марна $i$ дочасна, але $\epsilon$ в ній $i$ висока позначеність» $[13$, c. 105]. Над усім володарює час, його аксіологічна значимість незаперечна: «Чим була людина не знаючи, щяо таке Час? Не стала б розумна: час-бо - ие думка про смерть, а звідси - всі пристрасті изього світу. Звідси - вічне змагання і марнота марнот» [13, с. 105].

Ремінісценція із книги Еклезіаста творить простір вічного буття і нагадує про тлінність і дочасність людського існування. Найвищої емоційної напруги образ часу досягає у романі «Дзигар одвічний». Його герой - старий Діденко, наділений ліричною вдачею. Він осягає світ думкою і пензлем, тому в його останньому бажанні злились прощальний душевний порух і мрія узріти Вічність: «У синьому просторі вулиці $i$ над нею в небі $і$ справді відбулося те, про щзо він просив. Небо раптом здригнулося $і$ заяскріло - на сіру площину вуличі полилася тремтлива сонячна матерія. Усе раптом ожило, оновилося, й Діденкові здалося, що ось-ось воно з'явиться - величезне коло, дві тіні, одна показуватиме на першу поділку, а друга - на другу. «Вічний дзигар»- подумав раптом Діденко аж затремтівши від збудження $i$ від того, щэо привиддя, яке викликав, таки з'явилося» [12, с. 263]. В останню мить свого життя, старий уздрів як вічний дзигар ударив полум'ям, а за ним з'явилась чорна постать. Інший старий, герой повісті «Камінна луна», «сідаючи на сани», спостерігає, як розсипається його Дзигар: "Дув із пронизливим свистом вітер $i$ ніс золотистий пісок, який поступово засипав долину $і$ чоловіка, який самотньо в тій долині сидів. Його ноги були в тому піску вже по литки і поблискували в ньому золоті зерна: чоловік набирав того піску в долоні $і$ пересипав у другу. Здута вітром потеруха відсіювалася, 
творячи $і$ повітрі прозорий трикутник, а на вільну долоню падали тільки важкі зерна золота і квариу...» [14, с. 181]. Образ шкодючого вітру є передвісником лиха, а пісок - символізує смерть.

У повісті «Юнаки $з$ огненної печі» цей образ, на перший погляд, модифікується в бік традиційного порівняння: «...Я - піщинка загублена в цьому світі», проте авторська уява витворює апокаліптичні видива: «мене ганяє вітер по пустелі, адже поруч 3 кожним із безлічі світів існує ще й безліч пустель, які розкривають на піщинку беззубого, безмежного рота, Щоб ї̈ пожерти» [25, с. 99]. Молодий герой повісті приходить до власного розуміння Бога: це іє система цих світів і пустель [25, с. 99], оскільки автобіографізм повісті означений автором, то можна стверджувати, що письменник вкладає в уста героя своє судження: недаремно Бог кидає нас у мандрівки із хрестом на спині, бо життя - це і є хресний шлях на Голгофу.

Отже, як бачимо, у творах Валерія Шевчука образ Божий постає в багатьох іпостасях: він Всевидячий і милосердний, увінчаний вінком звершених чеснот; Божественний Логос, той, хто шле долю. Він Творець всього сущого і сам - як дерево несмертельне. Бог є любов. Він вселяє надію в людські серця, бо $є$ Володарем Раю. Залишаючись трансцендентним, невидимим цей сакральний Образ структурує цілісний інтертекст і сприяє розкриттю ідейно-естетичного задуму автора.

\section{Література}

1. Аверинцев С. Боже! Ты - Бог мой / С. Аверинцев // Литературная газета. 16.01.91. (5328). - №2. - С. 14.

2. Бердяев Н. О достоинстве христианства и недостоинстве христиан / Н. Бердяев // Человек. - 1991. - №5.

3. Булашев Г. Український народ в своїх легендах, релігійних поглядах та віруваннях / Г. Булашев. - К., 1992. - С. 414.

4. Головей В. Категорія священного: проблема етимології та семантики / В. Головей // Проблеми гуманітарних наук. Наукові записки Дрогобицького державного педагогічного університету. - Дрогобич, 2002. - Вип. 10. - 39 с.

5. Гуссерль Э. Цит. за Кнабе Т.С. Витгенштейн и Гуссерль / Э. Гусерль // Вопросы философии. - 1998. - №5. - С. 56-61.

6. Набитович I. Sacrum і Біблія в українській літературі / I. Набитович / [за ред. Ігоря Набитовича]. - Lublin Jngvarr, 2008. - 812 s.

7. Павлишин М. Мітологічне, релігійне та філософське у прозі Валерія Шевчука / М. Павлишин // Павлишин М. Канон та іконостас. - К., 1997. - С. 143-157.

8. Пивоварська А. Дім на горі. Розмова з Валерієм Шевчуком / А. Пивоварська // Сучасність. - 1993. - №2. - С. 54-60.

9. Українка Леся. Мамо, іде вже зима / Українка Леся. Твори : у 2-х томах. - К. : Наукова думка, 1987. - Т. 1. - 125 с.

(ㄷ Л. О. Донченко, 2012. 
10. Франко І. Із секретів поетичної творчості / І. Франко. - К., 1969.

11. Шевчук В. Відлунок / Валерій Шевчук // В. Шевчук. Барви осіннього саду. - К., 1986. - С. 410-427.

12. Шевчук В. Дзигар одвічний / Валерій Шевчук. - К., 1990. - 263 с.

13. Шевчук В. Ілля Турчиновський // Три листки за вікном / Валерій Шевчук. - К, 1986. - C. $15-137$.

14. Шевчук В. Камінна луна / Валерій Шевчук. - К., 1987. - 167 с.

15. Шевчук В. Крик півня на світанку // Барви осіннього саду / Валерій Шевчук. K., 1986. - C. 218-304.

16. Шевчук В. Мор / Валерій Шевчук // В. Шевчук. Птахи з невидимого острова. K., 1989. - С. 363-469.

17. Шевчук В. На полі смиренному // Валерій Шевчук // В. Шевчук. Птахи 3 невидимого острова. - К., 1989. - С. 5-189.

18. Шевчук В. Око прірви / Валерій Шевчук. - К., 1996. - 197 с.

19. Шевчук В. Постріл / Валерій Шевчук // В. Шевчук. Долина джерел. - К., 1981. C. 211-239.

20. Шевчук Валерій. Петро Утеклий // Три листки за вікном / Валерій Шевчук. К., 1986. - С. 137-285.

21. Шевчук В. Птахи з невидимого острова / Валерій Шевчук. - К., 1989. - 470 с.

22. Шевчук В. Свічення / Валерій Шевчук // В. Шевчук. Дім на горі. - К., 1989. C. 355-383.

23. Шевчук В. Стежка в траві / Валерій Шевчук. - Харків, 1994. - Т. 2. - 526 с.

24. Шевчук В. Три листки за вікном / Валерій Шевчук. - К., 1986. - 587 с.

25. Шевчук В. Юнаки з огненної печі / Валерій Шевчук // Дзвін. - 1996. - №3. C. $91-130$.

26. Юнг К. - Г. Архетип и символ / К. - Г. Юнг. - М., 1991.

Стаття надійшла до редакції 30.10 .2012 p. 